\title{
ANALISIS PENGARUH LEVERAGE TERHADAP NILAI PERUSAHAAN DENGAN KEPEMILIKAN MANAJERIAL DAN ARUS KAS BEBAS SEBAGAI VARIABEL PEMODERASI
}

\author{
Linawaty dan Agustin Ekadjaja \\ agustine@fe.untar.ac.id
}

\begin{abstract}
Abstrak: The purpose of this study is to examine whether or not the effect of leverage on firm value with management ownership and free cash flow as moderating variabel practice of manufacture firms listed in Indonesian Stock Exchange for period 20122014. Thirty five sample are selected by purposive sampling and used ordinary least square method to analysis. This study used secondary data such as firm financial statement that published during the observation year. Dependent variabel in this study is firm value practice of real estate firms listed in Indonesian Stock Exchange, while the independent variabels are leverage, management ownership, and free cash flow. The result shows that the impact of leverage is significant on firm value; Free Cash Flow is significant moderating leverage on firm, Management Ownership is not significant moderating leverage on firm value.
\end{abstract}

Keywords: Firm Value, Leverage, Management Ownership, Free Cash Flow

Abstrak: Penelitian ini bertujuan untuk mengetahui pengaruh leverage terhadap nilai perusahaan dengan kepemilikan manajerial dan arus kas bebas sebagai variabel pemoderasi pada perusahaan manufaktur yang terdaftar di Bursa Efek Indonesia. Sampel yang digunakan dalam penelitian ini adalah 35 perusahaan yang terdaftar di Bursa Efek Indonesia tahun 2012-2014. Data yang digunakan adalah data sekunder. Variabel terikat dalam penelitian ini adalah nilai perusahaan, sedangkan variabel bebas meliputi leverage, kepemilikan manajerial, dan arus kas bebas. Hasil penelitian menunjukkan Leverage berpengaruh signifikan terhadap nilai perusahaan; Arus Kas Bebas memoderasi nilai perusahaan dan Kepemilikan Manajerial tidak signifikan memoderasi leverage terhadap nilai perusahaan.

Kata kunci: Nilai Perusahaan, Leverage, Kepemilikan Manajemen, Arus Kas Bebas

\section{PENDAHULUAN}

Peningkatan investasi di Indonesia yang berlangsung pesat pada beberapa tahun terakhir membuat perusahaan-perusahaan yang tergabung dalam BEI berupaya meningkatkan nilai perusahaan. Optimalisasi nilai perusahaan yang merupakan tujuan perusahaan dapat dicapai melalui pelaksanaan fungsi manajemen keuangan. Nilai perusahaan dapat berlangsung secara efektif jika manajemen melaksanakan fungsinya sesuai dengan tujuan yang telah ditetapkan oleh perusahaan.

Leverage adalah salah satu mekanisme eksternal, yang dipercaya dapat mengurangi biaya agensi. Pemberi hutang seperti lembaga keuangan dan bank akan memantau manajer mengoptimalkan nilai perusahaan. Pemantauan ini memungkinkan pemegang hutang untuk mengevaluasi kelayakan perusahaan dalam menerima pinjaman dan mematuhi perjanjian hutang. Keputusan leverage akan menghasilkan insentif bagi manajer dengan 
tujuan manajer akan mengambil langkah meningkatkan nilai perusahaan, Sanda, et al. (2005).

Demand hypothesis menjelaskan bahwa perusahaan yang dikuasai oleh insider menggunakan hutang dalam jumlah besar untuk mendanai perusahaan. Dengan kepemilikan besar, pihak insider ingin mempertahankan efektivitas kontrol terhadap perusahaan. Supply hipothesis menjelaskan bahwa perusahaan yang dikontrol oleh insider memiliki debt agency cost kecil sehingga meningkatkan penggunaan utang. Hal ini menunjukkan bahwa kepemilikan manajerial dapat merangsang kebijakan hutang perusahaan, yang secara tidak langsung akan meningkatkan nilai perusahaan. Dengan kata lain, manajemen ownership dianggap mampu mendorong leverage dalam mempengaruhi firm value.

Penelitian yang diungkapkan oleh Wahyudi dan Pawestri (2006), mengungkapkan hal sebaliknya (research gap) yaitu dengan adanya kontrol yang ketat, menyebabkan manajer menggunakan hutang pada tingkat rendah untuk mengantisipasi kemungkinan terjadinya financial distress dan risiko kebangkrutan. Hal ini menunjukkan perbedaan penelitian mengenai pengaruh kepemilikan manajerial terhadap hubungan antara leverage dengan firm value.

\section{KAJIAN TEORI}

Agency Theory. Brigham dan Ehrhardt (2008 : 581) mengungkapkan penjelasan mengenai agency problem, dimana masalah keagenan dapat terjadi jika manajer dan pemegang saham memiliki tujuan yang berbeda. Konflik mungkin ketika manajer perusahaan memiliki kelebihan uang tunai yang tidak banyak digunakan untuk memaksimalkan harga saham.

Teori agensi menjelaskan bahwa struktur modal (equity dan liability) dibentuk untuk mengurangi terjadinya konflik antara kelompok kepentingan, seperti pemegang saham dan manajer . Jansen dan Meckling (1976:6) menjelaskan hubungan keagenan sebagai kontrak di mana satu atau lebih orang (principal) terlibat dengan orang lain (agen) untuk melakukan beberapa layanan atas nama mereka yang melibatkan pendelegasian sebagian wewenang pengambilan keputusan kepada agen. Jika kedua belah pihak untuk hubungan yang maximizers utilitas, ada alasan yang baik untuk percaya bahwa agen tidak akan selalu bertindak dalam kepentingan terbaik dari Principal. Principal dapat membatasi divergensi dari minatnya dengan mendirikan insentif yang tepat untuk agen dan yang dapat menimbulkan biaya monitoring untuk membatasi kegiatan menyimpang dari agen.

Kebijakan hutang dianggap mampu untuk mengurangi konflik keagenan tersebut. Hal ini dipertegas oleh Brigham dan Ehrhardt (2008 : 567) yang menyatakan bahwa tingkat hutang yang semakin besar dapat mempengaruhi perilaku manajer dalam pengambilan keputusan apakah menggunakan cash flow untuk pengeluaran atau untuk mengurangi kemungkinan terjadi kesulitan keuangan (bankruptcy )manajer akan berhati - hati dalam melakukan pengeluaran.

Trade off theory. Menurut Brigham dan Ehrhardt (2008:578), pengertian trade off theory of leverage, dimana nilai perusahaan leverage sama dengan nilai sebuah perusahaan unleveraged ditambah nilai efek samping, termasuk pajak yang dicadangkan dan biaya yang diharapkan karena kesulitan keuangan.

Teori ini menjelaskan bahwa pendanaan menggunakan hutang yang dilakukan oleh perusahaan dapat meningkatkan perusahaan untuk mengalami kesulitan keuangan. Hal ini 
disebabkan pembayaran bunga tetap yang besar setiap tahunnya tanpa adanya kepastian laba bersih. Bunga atas hutang dapat mengurangi pajak, ,tetapi hutang akan menimbulkan biaya yang terkait dengan kebangkrutan aktual atau potensial.

Signaling Theory. Brigham dan Ehrhardt (2008:579) menjelaskan mengenai signaling theory dimana manager memiliki informasi yang lebih baik dari investor luar, yang disebut sebagai informasi asimetri (asymmetric information) dimana informasi ini mempengaruhi struktur modal yang optimal. Manajer yang memiliki informasi lebih banyak dapat memberikan sinyal yang terpercaya.

Nilai perusahaan. Nilai perusahaan berbanding lurus dengan kemakmuran pemegang saham, semakin tinggi nilai perusahaan maka semakin tinggi pula tingkat kemakmuran perusahaan. Menurut Herry ( $2015: 170$ ):

"Rasio harga terhadap nilai buku merupakan ratio yang menunjukkan hasi perbandingan antara harga pasar per lembar saham dengan nilai buku per lembar saham. Rasio ini digunakan untuk mengukur tingkat harga saham apakah overvalued atau undervalued. Semakin rendah nilai PBV suatu saham maka saham tersebut dikategorikan undervalued, dimana sangat baik untuk investasi jangka panjang. Namun, rendahnya nilai PBV juga dapat mengindikasikan menurunnya kualitas dan kinerja fundamental emiten “

Price to book value ratio merupakan suatu rasio yang menyatakan perbandingan antara harga pasar per saham biasa yang beredar (common stock outstanding) yang tercatat di dalam laporan keuangan. Gitman dan Zutter (2012:83) mempertegas dengan pernyataan rasio nilai pasar / nilai buku memberikan penilaian tentang bagaimana investor melihat kinerja perusahaan. Hal ini terkait nilai pasar saham perusahaan untuk nilai buku dalam penilaian akuntansi yang ketat.

Leverage. Brigham dan Ehrhardt (2008 : 11) mengkategorikan leverage menjadi 2 yaitu financial leverage dan operating leverage, dengan penjelasan sebagai berikut: Financial leverage adalah sejauh mana tetap efek pendapatan (utang dan saham preferen) digunakan dalam struktur modal perusahaan. Jika persentase yang tinggi dari struktur modal perusahaan adalah dalam bentuk hutang dan saham preferen, maka perusahaan dikatakan memiliki tingkat tinggi leverage keuangan. Operasi leverage adalah sejauh mana biaya tetap yang digunakan dalam operasi perusahaan. Jika persentase yang tinggi dari total biaya adalah biaya tetap, maka perusahaan dikatakan memiliki operasi leverage yang tinggi.

Kebijakan hutang dapat diukur menggunakan DER (Debt to Equity Ratio). DER merupakan rasio yang menunjukkan perbandingan antara pembiayaan dan pendanaan melalui hutang dengan pendanaan melalui ekuitas.

Free Cash Flow. Pengertian yang diungkapkan oleh Brigham dan Erhardt (2008: 33) mengenai Free Cash Flow adalah arus kas yang tersedia untuk distribusi ke semua investor perusahaan (pemegang saham dan kreditur) setelah perusahaan telah membayar semua biaya (termasuk pajak) dan membuat investasi yang dibutuhkan dalam operasi untuk mendukung pertumbuhan.

Management Ownership. Management Ownership atau sama dengan employee stock ownership didefinisikan oleh Brigham dan Ehrhardt (2008: 552) yaitu Sebuah 
Kepemilikan Saham bagi Karyawan yang memfasilitasi kepemilikan karyawan saham di perusahaan tempat mereka bekerja yang dapat memotivasi karyawan untuk meningkatkan produktivitas.

\section{Variabel Independent $\quad$ Variabel Pemoderasi $\quad$ Variabel Dependent}

$\mathrm{H} 1$

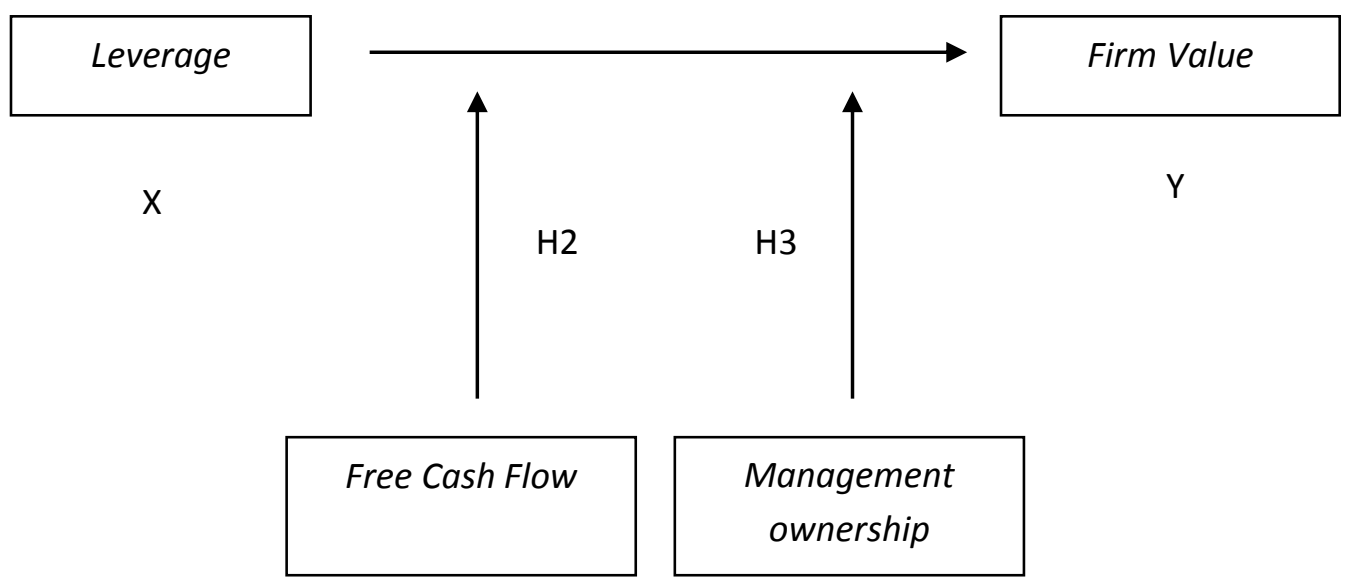

Gambar 1. Paradigma Penelitian

Penelitian ini terbagi menjadi tiga jenis variabel yaitu a) Variabel terikat (dependent) adalah variabel yang muncul akibat dipengaruhi oleh variabel bebas. Variabel terikat dalam penelitian ini yaitu Firm Value (Nilai perusahaan).; b) Variabel bebas (independent) adalah variabel yang mempengaruhi variabel lain atau dengan kata lain dianggap menjadi penyebab munculnya variabel terikat. Variabel bebas dalam penelitian ini yaitu Leverage; c) Variabel moderasi adalah variabel yang memperkuat atau memperlemah hubungan antara satu variabel dengan variabel lain. Variabel pemoderasi dalam penelitian ini yaitu

Free Cash Flow dan Management Ownership. Leverage diperlukan untuk memaksimalkan sumber pendanaan hutang yang mempengaruhi nilai perusahaan, maka hipotesis pertama:

$\mathrm{Ha}_{1}$ : Leverage memiliki pengaruh signifikan terhadap Firm Value. Free Cash Flow yang baik akan mempengaruhi leverage dan nilai perusahaan

maka hipotesis kedua:

$\mathrm{Ha}_{2}$ : Free Cash Flow memiliki pengaruh terhadap hubungan antara leverage terhadap firm value.

Kepemilikan Manajerial berpengaruh terhadap leverage dan nilai perusahaan maka hipotesis ketiga:

Ha3: Managerial ownership memiliki pengaruh terhadap hubungan antara leverage terhadap firm value 


\section{METODE}

Populasi dalam penelitian ini adalah perusahaan manufaktur yang terdapat di Bursa Efek Indonesia pada tahun 2012 sampai dengan tahun 2014. Sampel yang diambil terdiri dari sektor manufaktur yang terdiri perusahaan industry dasar dan kimia (basic industry and chemicals), perusahaan aneka industry (miscellaneous industry), dan perusahaan industri konsumen (consumer goods industry). Perusahaan yang akan diteliti hanya dibatasi pada perusahaan di Indonesia yang menyajikan kepemilikan manajerial dalam laporan keuangan yang disajikan.

Metodologi penelitian ini adalah hubungan sebab-akibat (kausalitas), yaitu suatu metode yang menjelaskan pengaruh variabel independen terhadap variabel dependen dengan diperkuat atau diperlemah oleh variabel pemoderating.

Variabel Penelitian. Definisi operasional variabel dalam penelitian ini adalah sebagai berikut:

a. Firm Value. Proxy dari firm value dalam penelitian ini adalah perbandingan antara harga pasar per lembar saham biasa terhadap nilai buku per lembar saham biasa, atau sering disebut Price Book Value (PBV).

$$
\begin{gathered}
\text { Book Value per share of Common Stock }= \\
\frac{\text { Common Stock Equity }}{\text { Number of shares of Common Stock outstanding }} \\
\text { Price Book Value }=\frac{\text { Market price per share of Common Stock }}{\text { BookValue per share of Common Stock }}
\end{gathered}
$$

b. Leverage. Proxy dari Leverage pada penelitian ini adalah perbandingan antara total hutang perusahaan terhadap total modal, atau sering disebut Debt to Equity Ratio (DER).

$$
\text { DER }=\frac{\text { Total debt }}{\text { Total equity }}
$$

c. Management Ownership. Proxy dari Management Ownership dalam penelitian ini adalah perbandingan antara jumlah share capital yang dimiliki oleh management terhadap total share capital. Rumus Management Ownership (MOW) menggunakan rasio:

$$
\text { MOW }=\frac{\text { Total Managemen Share Capital }}{\text { Total Share Capital }}
$$

d. Free Cash Flows. Proxy dari free cash flows dalam penelitian ini adalah pengurangan antara net operating profit after tax dengan net investment in operating capital, atau sering disebut dengan FCF rasio. Rumus free cash flow ratio adalah sebagai berikut: Net Operating Working Capital $($ NOWC $)=$ Operating Current Asset Operating Current Liabilities.

Total Net Operating Capital $(T N O C)=N O W C+$ Operating Long Term Asset Net investment in operating capital (NOPAT)

$$
\begin{gathered}
=\text { Current year's TNOC }- \text { Previous year TNOC } \\
\text { FCF Rasio = NOPAT - Net investment in operating capital }
\end{gathered}
$$




\section{HASIL DAN PEMBAHASAN}

Statistik Deskriptif. Statistik deskriptif memberikan gambaran atau deskripsi atas sampel yang digunakan dalam penelitian. Statistik deskriptif dalam penelitian ini akan menunjukkan ukuran statistik seperti nilai minimum, nilai maksimum, nilai rata - rata (mean), standar deviasi, dan ukuran sampel dari setiap variabel yang digunakan dalam penelitian baik variabel bebas maupun variabel terikat.

Tabel 1. Hasil Pengujian Deskriptif

\begin{tabular}{lrrrrr}
\hline & $\mathrm{N}$ & \multicolumn{1}{c}{ Minimum } & \multicolumn{1}{c}{ Maximum } & \multicolumn{1}{l}{ Mean } & \multicolumn{1}{c}{ Std. Deviation } \\
\hline PBV & 105 & $-5,75169$ & 4,07135 &, 9702736 & 1,11396574 \\
DER & 105 & $-31,78137$ & 5,86859 &, 6837607 & 3,43203916 \\
DER FCF & 105 & $-1.43169 \mathrm{E}+13$ & $5.7912 \mathrm{E}+18$ & $1.0108 \mathrm{E}+18$ & $6.2244 \mathrm{E}+20$ \\
& & & & & \\
DER*MOW & 105 &,- 38569 &, 54183 & & \\
$\begin{array}{l}\text { Valid N } \\
\text { (listwise) }\end{array}$ & 105 & & & & \\
\hline
\end{tabular}

Berdasarkan Tabel 1, nilai minimum untuk Leverage adalah -31,78137 dan maksimum adalah 5,86859. Rata-rata nilai untuk nilai Leverage adalah ,9702736 dengan standar deviasi sebesar 1,11396574. Nilai minimum Leverage yang dimoderasi oleh Free Cash Flows adalah $-1.43169 \mathrm{E}+13$ yang dimiliki oleh dan nilai maksimum sebesar 5.7912E+18. Nilai rata-rata Likuiditas adalah 1.0108E+18 dengan nilai standar deviasi 6.2244E+20. Nilai minimum Leverage yang dimoderasi oleh Management Ownership adalah -,385698 dan nilai maksimum dimiliki oleh ,54183 sebesar ,0364492. Nilai rata-rata Likuiditas adalah 1.0108E+18 dengan nilai standar deviasi ,08898281. Variabel dependen nilai perusahaan memiliki nilai minimum $-5,75169$ dan nilai maksimum 4,07135.

Uji Multikolonieritas. Uji Multikolinearitas bertujuan untuk menguji apakah dalam suatu model regresi terdapat korelasi antar variabel independen.

Tabel 2. Hasil Pengujian Multikolinearitas

\begin{tabular}{|c|c|c|c|c|c|c|c|c|}
\hline \multicolumn{2}{|c|}{ Model } & $\begin{array}{r}\text { Unstandc } \\
\text { Coeffic }\end{array}$ & $\begin{array}{l}\text { rdized } \\
\text { ents }\end{array}$ & $\frac{\text { Coefficients }^{a}}{\text { Standardized }}$ & \multirow[t]{2}{*}{$t$} & \multirow[t]{2}{*}{ Sig. } & \multicolumn{2}{|c|}{$\begin{array}{c}\text { Collinearity } \\
\text { Statistics }\end{array}$} \\
\hline & (Constant) & $\begin{array}{l}\mathrm{B} \\
886\end{array}$ & $\begin{array}{l}\text { Std. } \\
\text { Error } \\
095\end{array}$ & Beta & & & $\begin{array}{c}\text { Tolera } \\
\text { nce }\end{array}$ & VIF \\
\hline \multirow{3}{*}{1} & DER & 200 & ,029 & 615 & 6,808 &, 000 & ,767 & 1,303 \\
\hline & $\mathrm{DER} * \mathrm{FCF}$ & $\begin{array}{r}4,384 \mathrm{E}- \\
014\end{array}$ & ,000 & ,245 & 3,087 & ,003 & ,996 & 1,004 \\
\hline & DER*MOW & $-1,544$ & 1,131 &,- 123 & $-1,364$ &, 175 & ,768 & 1,303 \\
\hline
\end{tabular}


Seluruh nilai VIF pada penelitian ini berada di bawah angka 10 dan nilai tolerance lebih besar dari 0,1. Maka dapat disimpulkan bahwa model regresi ini bebas dari masalah multikolinearitas.

Uji Heteroskedastisitas. Uji Heterokedastisitas dilakukan untuk menguji apakah dalam suatu model regresi terjadi ketidaksamaan varians antar residual pengamatan dengan menggunakan uji glejser.

Tabel 3. Hasil Pengujian Glejser

\section{Coefficients $^{\mathrm{a}}$}

\begin{tabular}{|c|c|c|c|c|c|}
\hline \multirow[t]{2}{*}{ Model } & \multicolumn{2}{|c|}{$\begin{array}{c}\text { Unstandardized } \\
\text { Coefficients }\end{array}$} & \multirow{2}{*}{$\begin{array}{c}\begin{array}{c}\text { Standardized } \\
\text { Coefficients }\end{array} \\
\text { Beta }\end{array}$} & \multirow[t]{2}{*}{$T$} & \multirow[t]{2}{*}{ Sig. } \\
\hline & $B$ & Std. Error & & & \\
\hline (Constant) &, 710 & ,060 & & 11,902 & ,000 \\
\hline 1 DER & ,019 & ,018 & , 117 & 1,043 & ,299 \\
\hline DER*FCF & $-6,491 \mathrm{E}-015$ & ,000 &,- 071 &,- 728 & ,469 \\
\hline DER*MOW & $-1,210$ & ,711 &,- 190 & $-1,702$ & ,092 \\
\hline
\end{tabular}

a. Dependent Variabel: ABSRES

Dari Tabel terlihat bahwa nilai signifikansi DER, FCF dan MOW lebih besar dari 0,05 maka dapat disimpulkan bahwa model regresi ini telah memenuhi persyaratan asumsi klasik heterokedastisitas.

Uji Normalitas. Uji normalitas dilakukan dengan menggunakan uji Kolmogorov-smirnov. Kriteria yang digunakan adalah pengujian dua arah (two tailed test), yaitu membandingkan $p$ value yang diperoleh dengan taraf signifikansi yang ditentukan, dalam penelitian ini taraf signifikansinya adalah 0,05 .

Tabel 4. Uji Kolmogorov-smirnov

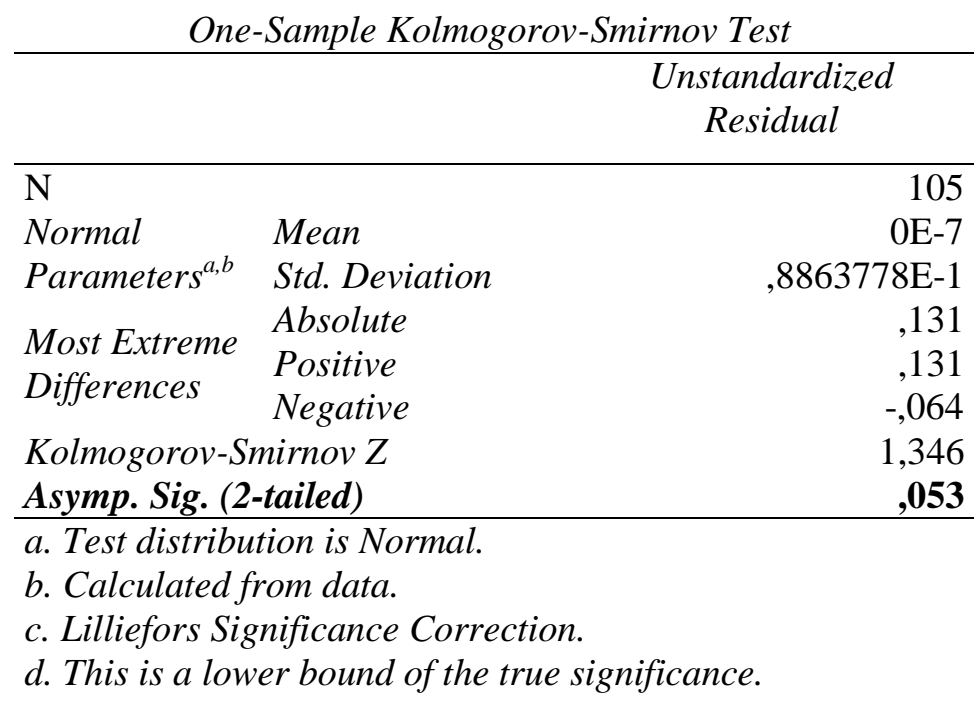

Nilai probabilitas sebesar 0.053 , lebih besar dari 0,05 , maka dapat disimpulkan data terdistribusi normal atau memenuhi persyaratan uji normalitas. 
Uji Koefisien Determinan ( $R$ Square). Nilai koefisien determinasi adalah antara nol dan satu. Nilai R square yang kecil artinya kemampuan variabel-variabel independen dalam menjelaskan variabel dependen terbatas.

Tabel 5. Hasil Pengujian Determinasi

\begin{tabular}{|c|c|c|c|c|c|}
\hline & & & Model Summ & $n a r y^{b}$ & \\
\hline Model & $R$ & $R$ Square & $\begin{array}{l}\text { Adjusted } R \\
\text { Square }\end{array}$ & $\begin{array}{l}\text { Std. Error of the } \\
\text { Estimate }\end{array}$ & Durbin-Watson \\
\hline 1 &, $606^{\mathrm{a}}$ & ,367 & ,348 & ,8994455E-1 & 2,160 \\
\hline
\end{tabular}

Nilai koefisien korelasi $\mathrm{R}$ dari hasil pengolahan data adalah 0,606 yang menunjukkan bahwa hubungan antara nilai perusahaan dengan variabel independennya adalah kuat.

Uji t (Uji Signifikansi Parsial). Uji statistik t dari tabel 2, menunjukkan seberapa jauh pengaruh satu variabel penjelas atau independen secara individual dalam menerangkan variasi variabel dependen. Variabel Leverage dan variabel Leverage dari tabel 2 yang dimoderasi oleh Free Cash Flows menghasilkan angka signifikan 0,000 dan 0,003, lebih kecil dari 0,05. Hal ini menunjukkan bahwa variabel leverage dan variabel Leverage yang dimoderasi oleh Free Cash Flows memiliki pengaruh yang positif terhadap nilai perusahaan manufaktur.

Variabel Leverage yang dimoderasi oleh Management Ownership dari tabel 2 menghasilkan angka signifikan 0,175, lebih besar dari 0,05. Hal ini menunjukkan bahwa variabel leverage yang dimoderasi oleh Management Ownership tidak memiliki pengaruh yang signifikan terhadap nilai perusahaan manufaktur yang terdaftar di BEI.

Analisis regresi moderasi. Berdasarkan hasil pengujian secara parsial, maka dapat dibuat suatu model regresi dari tabel 2, sebagai berikut.

$\mathrm{Y}=\alpha+\beta_{1} \mathrm{x}_{1}+\beta_{2} \mathrm{x}_{1} * \mathrm{z}_{1}+\beta_{3} \mathrm{x}_{1} * \mathrm{z}_{2}+\varepsilon$

$\mathrm{Y}=0,886+0,200 \mathrm{DER}+0,438 \mathrm{E}-14 \mathrm{DER} * \mathrm{FCF}-1,544 \mathrm{DER} * \mathrm{MOW}+\varepsilon$

Dengan penjelasan tiap variabel dalam model regresi sebagai berikut:

$\mathrm{Y}=$ Firm Value $; \mathrm{DER}=$ Leverage $; \mathrm{FCF}=$ Free Cash Flows $;$ MOW = Management Ownership $; \varepsilon=$ error / kesalahan.

Maka dapat disimpulkan apabila Leverage naik sebesar satu satuan dan nilai variabel lainnya tetap, maka nilai perusahaan akan naik sebesar 0,200 satuan. Jika nilai Management Ownership naik sebesar satu satuan dan nilai variabel lainnya tetap, maka akan memperkuat leverage dalam mendorong kenaikan nilai perusahaan sebesar 0,438E - 13 satuan. Jika nilai Free Cash Flows naik sebesar satu satuan dan nilai variabel lainnya tetap, maka akan memperkuat leverage dalam mendorong penurunan nilai perusahaan sebesar 1,544 satuan. 
Uji f (Uji Signifikansi Simultan). Dasar pengambilan keputusannya adalah jika nilai signifikansi lebih kecil dari 0,05 maka model regresi layak untuk digunakan.

Tabel 9. Hasil Pengujian Simultan (ANOVA ${ }^{\mathbf{a}}$ )

\begin{tabular}{lrrrrr}
\hline Model & Sum of Squares & Df & Mean Square & \multicolumn{1}{c}{$F$} & Sig. \\
\hline Regression & 47,346 & 3 & 15,782 & 19,508 &, $000^{\mathrm{b}}$ \\
Residual & 81,709 & 101 &, 809 & & \\
Total & 129,056 & 104 & & & \\
\hline
\end{tabular}

a. Dependent Variabel: $P B V$

Nilai yang dihasilkan dari pengujian simultan dari Tabel 9 adalah 0,000. Maka dapat disimpulkan bahwa seluruh variabel independen secara simultan mempengaruhi variabel dependen. Oleh karena itu, hipotesis yang menyatakan bahwa seluruh variabel independen secara bersama berpengaruh terhadap nilai perusahaan dapat diterima dengan tingkat keyakinan sebesar $95 \%$.

Pengaruh Leverage, Leverage dimoderasi FCF dan Leverage dimoderasi Management Ownership terhadap Firm Value. Berdasarkan hasil pengolahan dengan menunjukkan bahwa nilai adjusted $R$-Squared sebesar 34,8\%. Hal ini berarti variabel-variabel independen yaitu Leverage, Leverage yang dimoderasi Free Cash Flows, dan Leverage yang dimoderasi Management Ownership dalam regresi dapat menjelaskan variasi variabel dependen yaitu nilai perusahaan adalah sebesar 34,8\%.

Pengaruh Leverage terhadap Firm Value. Hasil pengujian statistic dengan uji t menyimpulkan bahwa leverage berpengaruh signifikan terhadap nilai perusahaan. Variabel leverage dapat digeneralisasi untuk mewakili keseluruhan sampel perusahaan manufaktur yang terdaftar di BEI periode 2012-2014. Hasil penelitian ini serupa dengan penelitian yang dilakukan oleh Kouki dan Said (2011), Sulong et al. (2013), dan Mai (2014) bahwa Leverage (DER) berpengaruh positif dan signifikan terhadap PBV. Hasil penelitian ini mengindikasikan bahwa Leverage yang dimiliki oleh perusahaan menjadi suatu pertimbangan penting yang diambil oleh investor dalam berinvestasi. Hal ini dikarenakan peningkatan Leverage di dalam perusahaan dianggap sebagai signal positif bagi perusahaan dalam melakukan investasi perusahaan di masa datang, dengan harapan pendapatan perusahaan akan meningkat. Dengan demikian para investor menjadi tertarik untuk menanam saham pada perusahaan. .

Pengaruh Leverage terhadap firm value sesuai dengan teori-teori yang digunakan dalam penelitian ini, yaitu agency theory, capital structure theory, trade off theory, dan signaling theory. Agency Theory menjelaskan bahwa struktur modal (equity dan liability) dibentuk untuk mengurangi terjadinya konflik antara kelompok kepentingan, seperti pemegang saham dan manajer. Kebijakan hutang dianggap mampu untuk mengurangi konflik keagenan tersebut (Brigham dan Enhardt, 2008). Dalam hal ini, kebijakan hutang dianggap mampu dalam meningkatkan nilai perusahaan, sehingga dapat mengurangi konflik keagenan yang terjadi antara manajer dengan pemilik perusahaan. Hal ini yang membuat leverage berpengaruh secara signifikan terhadap nilai perusahaan.

Jika dikaitkan dengan capital structure theory, didalam teori ini menunjukkan bahwa nilai perusahaan tidak terkait dengan strategi pendanaan perusahaan, dengan kondisi tidak ada brokerage cost, pajak, bancruptcy cost, investor dapat melakukan pinjaman dengan nilai yang sama, tidak adanya informasi asimetris antara pihak manajemen dengan para 
pemegang saham, dan laba tidak dipengaruhi penggunaan hutang (Brigham dan Ehrhardt, 2008). Dalam penelitian ini, laba perusahaan dipengaruhi oleh penggunaan hutang, oleh sebab itu dapat disimpulkan bahwa nilai perusahaan terkait dengan strategi pendanaan perusahaan, yaitu leverage. Dari hasil pengujian dan dikaitkan dengan teori yang ada, maka dapat disimpulkan bahwa Leverage mempengaruhi nilai perusahaan secara signifikan.

Pengaruh Leverage yang dimoderasi Free Cash Flows terhadap Firm Value. Hasil pengujian statistic dengan uji t menyimpulkan bahwa leverage yang dimoderasi Free Cash Flows (DER*FCF) berpengaruh signifikan terhadap nilai perusahaan. Hal ini terbukti dengan ditunjukkannya adanya pengaruh yang signifikan atas leverage (DER) dimoderasi Free Cash Flows (FCF) terhadap nilai perusahaan yang diproksikan dengan price book value (PBV) dimana nilai prob $=0,003$ (prob < 0,05). Dengan demikian, variabel leverage yang dimoderasi Free Cash Flows dapat digeneralisasi untuk mewakili keseluruhan sampel perusahaan manufaktur yang terdaftar di BEI periode 2012-2014.

Hasil penelitian ini serupa dengan penelitian yang dilakukan oleh Kouki dan Said (2011), Sulong et al. (2013), dan Gusti (2008) bahwa Leverage yang berpengaruh signifikan terhadap nilai perusahaan semakin diperlemah secara negatif oleh adanya Free Cash Flow yang besar dalam perusahaan. Perusahaan dengan Free Cash Flow yang tinggi akan menurunkan tingkat hutang yang digunakan dalam perusahaan dalam meningkatkan nilai perusahan. Hal ini dikarenakan perusahaan merasa mampu untuk meningkatkan nilai perusahaan tanpa perlu menambahkan hutang dalam perusahaan, dengan adanya Free Cash Flow yang tinggi.

Pengaruh Leverage yang dimoderasi Management Ownership terhadap Firm Value. Hasil pengujian statistic dengan uji t menyimpulkan bahwa leverage yang dimoderasi Management Ownership (DER*MOW) tidak berpengaruh signifikan terhadap nilai perusahaan. Hal ini ditunjukkan dengan tidak adanya pengaruh yang signifikan atas leverage (DER) dimoderasi Management Ownership (MOW) terhadap nilai perusahaan yang diproksikan dengan price book value (PBV) dimana nilai prob $=0,175$ (prob $>0,05)$.

Hasil penelitian ini serupa dengan penelitian yang dilakukan oleh Mardiyati et al. (2012), Gusti (2008), Daud et al. (2015), Sujoko dan Soebiantoro (2007), serta Rahmawati (2012) bahwa Management Ownership tidak dapat menjadi variabel yang memoderasikan pengaruh antara Leverage terhadap Firm Value. Akan tetapi, penelitian ini tidak serupa dengan penelitian yang dilakukan oleh Kouki dan Said (2011) dan Sulong et al. (2013) bahwa Management Ownership dapat menjadi variabel yang memoderasikan antara Leverage terhadap Firm Value. Hal ini dikarenakan oleh beberapa sebab yaitu: (a) keputusan penggunaan sumber pendanaan dari hutang kurang erat kaitannya dengan struktur kepemilikan manajemen dalam perusahaan, tetapi lebih dipengaruhi oleh peluang keberhasilan atau tingkat resiko aktivitas yang didanai dalam meningkatkan nilai perusahaan; (b) Kepemilikan manajerial dalam perusahaan yang menjadi sampel masih dikatakan sangat kecil, sehingga tidak mempengaruhi kemampuan Manajemen dalam mengambil keputusan hutang dalam perusahaan secara signifikan.

Hasil pengujian penelitian ini menunjukkan bahwa Management Owneship tidak dapat Memperkuat atau memperlemah Leverage dalam mempengaruhi nilai perusahaan. Dalam analisis pembahasan dalam penelitian ini menunjukkan bahwa alasan managerial ownership tidak memoderasi leverage dalam mempengaruhi nilai perusahaan disebabkan oleh keputusan penggunaan sumber pendanaan dari hutang kurang erat kaitannya dengan 
struktur kepemilikan manajemen dalam perusahaan, tetapi lebih dipengaruhi oleh peluang keberhasilan atau tingkat resiko aktivitas yang didanai dalam meningkatkan nilai perusahaan dan kepemilikan manajerial dalam perusahaan yang menjadi sampel masih dikatakan sangat kecil, sehingga tidak mempengaruhi kemampuan Manajemen dalam mengambil keputusan hutang dalam perusahaan secara signifikan, sehingga dapat disimpulkan bahwa management ownership tidak dapat menjadi variabel moderating antara leverage terhadap nilai perusahaan.

\section{PENUTUP}

Simpulan. Penelitian ini bertujuan untuk memperoleh bukti empiris mengenai pengaruh Leverage, Leverage dimoderasi oleh Management Ownership, dan Leverage yang dimoderasi oleh Free Cash Flow terhadap nilai perusahaan pada perusahaan manufaktur yang terdapat di Bursa Efek Indonesia pada tahun 2012 sampai dengan tahun 2014. Hasil pengolahan data menunjukkan bahwa variabel independen yang digunakan dalam penelitian telah memenuhi syarat uji asumsi klasik, sehingga variabel independen yang digunakan sudah layak.

Hasil uji hipotesis pertama menunjukkan bahwa variabel Leverage mempunyai pengaruh yang signifikan terhadap nilai perusahaan. Hasil uji hipotesis kedua menunjukkan bahwa variabel Leverage yang dimoderasi free cash flow mempunyai pengaruh yang signifikan terhadap nilai perusahaan. Hasil uji hipotesis ketiga menunjukkan bahwa variabel Leverage yang dimoderasi Management Ownership tidak mempunyai pengaruh yang signifikan terhadap nilai perusahaan.

Berdasarkan uji $\mathrm{F}$, dapat disimpulkan seluruh variabel independen secara simultan mempengaruhi variabel dependen. Oleh karena itu, hipotesis yang menyatakan bahwa seluruh variabel independen secara bersama berpengaruh terhadap nilai perusahaan dapat diterima. Hasil uji R menunjukkan bahwa hubungan yang terjadi antara nilai perusahaan dengan variabel independen adalah kuat.

Saran. Penelitian ini masih memiliki banyak keterbatasan, diantaranya adalah sebagai berikut: (a) Kategori perusahaan yang dijadikan sampel dalam penelitian masih terbatas hanya pada perusahaan manufaktur; (b) Penelitian ini dilakukan dalam periode yang singkat, yaitu periode 2012-2014; dan (c) Jumlah variabel independen yang digunakan hanya tiga variabel, yaitu Leverage, Leverage yang dimoderasi Free Cash Flow, dan Leverage yang dimoderasi Management Ownership.

Saran yang dapat diberikan dalam penelitian ini berkaitan dengan kategori perusahaan yang dijadikan sampel dalam penelitian masih terbatas hanya pada perusahaan manufaktur adalah bahwa objek penelitian selanjutnya diharapkan tidak hanya terbatas pada perusahaan manufaktur saja, tetapi juga industri dari sektor lainnya atau berasal dari semua jenis perusahaan publik atau bahkan melakukan perbandingan antara jenis perusahaan publik mengenai kebijakan perusahaan tersebut terhadap nilai perusahaan.

Saran yang dapat diberikan dalam penelitian ini berkaitan dengan periode yang singkat, yaitu periode 2012-2014 adalah bahwa untuk penelitian selanjutnya, hendaknya perlu memperbesar ukuran sampel. Hal ini dapat dilakukan dengan menambah periodisasi penelitian sehingga diperoleh sampel yang lebih besar dan memberikan kemungkinan yang lebih besar untuk memperoleh kondisi yang sebenarnya.

Saran yang dapat diberikan dalam penelitian ini berkaitan dengan keterbatasan jumlah variabel independen yang digunakan, yaitu hanya tiga variabel, yaitu Leverage, 
Leverage yang dimoderasi Free Cash Flow, dan Leverage yang dimoderasi Management Ownership adalah bahwa objek penelitian selanjutnya diharapkan menggunakan lebih banyak variabel-variabel lain yang dapat menjelaskan pengaruhnya terhadap Firm Value. Variabel-variabel lain yang dapat digunakan adalah seperti profitabilitas, kebijakan dividen, size perusahaan, kepemilikan institusional, Investment Opportunity, yang dapat dijadikan variabel $\mathrm{X}$ maupun variabel moderating.

\section{DAFTAR RUJUKAN}

Agoes, Sukrisno; Ardana, I Cenik; dan Daryanti, Sri. (2007) Ketentuan pokok pembuatan dan persetujuan skripsi serta ketentuan pokok pelaksanaan ujian komprehensif/skripsi. Jakarta: Badan Penerbit Universitas Tarumanagara.

Anthony, Robert N. \& Govindarajan, Vijay. (2003) Management control system. Jakarta: Salemba Empat.

Brigham, Eugene F \& Ehrhardt., Michael C. (2008) Financial management: theory and practice. Twelfth Edition. New York: South Western.

Christiawan, Yulius J. \& Tarigan, Josua. (2007) Kepemilikan manajerial: kebijakan hutang, kinerja, dan nilai perusahaan. Jurnal Akuntansi dan Keuangan. Vol 9. (1).

Daud, Ardika; Nangoy, Sientje; \& Saerang, Ivonne. (2015) Pengaruh kepemilikan manajerial dan institusional terhadap kebijakan hutang pada perusahaan non manufaktyr di bursa efek indonesia. Jurnal Berkala Ilmiah Efisiensi, Vol 15. (5).

Fama, Eugene F dan French, Kenneth R. (1998) Taxes, financing decisions, and firm value. The Journal of Finance, Vol. LIII. (3).

Ghozali, Imam. (2012) Aplikasi analisis multivariate dengan program ibm spss 20. Semarang: Badan Penerbit Universitas Diponegoro.

Gitman, Lawrence J. dan Zutter (2012). Principles of managerial Finance, $13^{\text {th }}$ Edition. England Pearson.

Gusti, Bertha Firyanni. (2013) Pengaruh free cash flows dan struktur kepemilikan saham terhadap kebijakan hutang dengan investment opportunity set sebagai variabel moderatig. Thesis: Program Studi Akuntansi Fakultas Ekonomi. Universitas Negeri Padang.

Hasan, Mudrika Alamsyah. (2014) Pengaruh kepemilikan manajerial (studi pada perusahaan-perusahaan industri dasar dan kimia yang terdaftar di bei, free cash flow, dan ukuran perusahaan terhadap kebijakan hutang. Jurnal Akuntansi, Vol. 3. (1).

Hery. (2015) Analisis Laporan Keuangan. Yogyakarta. CAPS (Center fo Academic Publishing Services)

Husnan, Suad. (2001) Corporate governance dan keputusan pendanaan: perbandingan kinerja perusahaan dengan pemegang saham pengendali perusahaan multinasional dan bukan multinasional. Journal of Accounting, Management, Economic Research. Hal. 1-10.

Ikatan Akuntan Indonesia. (2012) Standar Akuntansi Keuangan. Jakarta: Penerbit Dewan Standar Akuntansi Keuangan Ikatan Akuntansi Indonesia (DSAK IAI).

Jensen, Michael C. (1986) Agency cost of free cash flow, corporate finance, and takeovers. American Economic Review, Vol. 76. (2). pp. 323-329.

Jensen, Michael C. dan Meckling, William H. (1976) Theory of the firm: managerial behaviour, agency cost, and ownership structure. Journal of Financial Economics 3, pp. 305-360. North-Holland Publishing Company. 
Kartikahadi, Hans et al. (2013) Akuntansi keuangan berdasarkan sak berbasis ifrs. Jakarta: Badan Penerbit Salemba Empat.

Kieso, Weygandt; Warfield. (2011) Intermediate accounting ifrs edition. Vol 1. United States of America: Wilay.

Kouki, Mondher \& Said, Hatem Ben. (2011) Does management ownership explain the effect of leverage on firm value? An analaysis of french listed firms. Journal of Business Studies Quarterly, Vol 3, pp.169-186.

Mai, Muhamad Umar. (2014) Pengaruh growth dan leverage terhadap price to book value dalam mediasi return on equity dan dividen payout Ratio. Performance, Vol. 19. (1). Maret 2014.

Mardiyati, Umi; Ahmad \& Gatot Nazir; Putri, Ria. (2012) Pengaruh kebijakan dividen, kebijakan hutang, dan profitabilitas terhadap nilai perusahaan manufaktur yang terdapat di bursa efek indonesia. Jurnal Riset Manajemen Sains Indonesia (JRMSI), Vol. 3. (1).

Putri, Imanda Firmantyas \& Nasir, Mohammad. (2006) Analisis persamaan simultan kepemilikan manajerial, kepemilikan institusional, risiko, kebijakan hutang, dan kebijakan dividen dalam perspektif teori keagenan. Simposium Nasional Akuntansi (SNA) IX, Padang, 23-26 Agustus 2006.

Rahmawati, Apriliana Nuzul. (2012)Analisis faktor kebijakan hutang yang mempengaruhi nilai perusahaan. Thesis: Program Studi Akuntansi Fakultas Ekonomika dan Bisnis. Universitas Diponegoro.

Rakhimsyah, Leli Amnah \& Barbara Gunawan, (2011) Pengaruh keputusan investasi, keputusan kendanaan, kebijakan dividen, dan tingkat suku bunga terhadap nilai perusahaan. Jurnal Investasi, Vol. 7. (1).

Sanda et al (2005) Corporate governance mechanisms and firm financial performance in nigeria. African Economic Research Consortium Paper 149, Maret 2005.

Sujoko \& Soebiantoro, Ugy. (2007) Pengaruh struktur kepemilikan saham, leverage, faktor intern dan factor ekstern terhadap nilai perusahaan (studi empirik pada perusahaan manufaktur dan non manufaktur di bursa efek jakarta). Jurnal Manajemen dan Kewirausahaan, Vol 09. (1). Hal 41-48.

Sulong et al. (2013) Managerial ownership, leverage, and audit quality impact on firm performance: evidence from the Malaysian Ace Market. Accounting and Taxation, Vol. 5. (1).

Tarjo. (2005) Analisa free cash flow dan kepemilikan manajerial terhadap kebijakan utang pada perusahaan publik di indonesia. Jurnal Riset Akuntansi Indonesia, Vol. 8. (1).

Taswan; Soliha, Euis. (2002) Pengaruh kebijakan hutang terhadap nilai perusahaan serta beberapa faktor yang mempengaruhinya. Jurnal Bisnis dan Ekonomi, September 2002.

United Nations Conference Trade and Development. April 2014. World Investment Report 2014.

Wahidahwati. (2002) Kepemilikan manajerial dan agency conflicts: Analisis persamaan simultan non linier dari kepemilikan manajerial, penerimaan resiko (risk taking), kebijakan utang dan kebijakan dividen. Simposium Nasional Akuntansi (SNA) V.

Wahyudi, Untung dan Pawestri, Hartini Prasetyaning. (2006) Implikasi struktur kepemilikan terhadap nilai perusahaan dengan keputusan keuangan sebagai variabel intervening. Simposium Nasional Akuntansi (SNA). Vol. IX. 